\title{
Role of Corporate Governance on the Performance of Insurance Companies of Nepal
}

\author{
Sushil Dev Subedi ${ }^{1}$
}

\begin{abstract}
The objective of this paper is to analyze the role of corporate governance on the financial performance of insurance companies. The study used descriptive cum causal relational research design. Firm ownership and board size are considered as the key variable of corporate governance while debt to equity ratio, firm size, firm age and firm growth are considered as control variables. The dependent variable firm performance is measured by return on asset (ROA) and return on equity (ROE). All the 40 insurance companies are considered as population of the study. The study used convenient sampling technique for selection of the sample. Seven out of 18 life insurance companies and eight out of 20 nonlife insurance companies are selected as sample. The study used five year data from 2009/10 to 2016/17 with 135 firm year observations. Data were collected from mail survey and published data from respective insurance company and Beema Samiti. Data were analyzed using a multiple linear regression model.The study concluded that corporate governance affects the firm performance in Nepalese insurance sector. Board size has a negative impact on ROA while firm size and firm ownership has a positive impact on ROA and ROE. The variable debt to equity has the negative and significant impact on $R O E$ respectively.
\end{abstract}

Key words: corporate governance, board size, firm ownership, firm, size, firm age, return assets

\section{Introduction}

Corporate governance is defined as the way in which stakeholders of the organization have an influence over the management of an organization (Shah, Butt, \& Saeed, 2011). Corporate governance is rules and disciplines which rule, direct and control an organization (B.K. et al., 2019). It makes responsible and accountable the board of directors and the top level management. Corporate governance is the mechanisms, processes and relations by which corporations are

1 Mr. Subedi is director at Beema Samiti, Kathmandu, Nepal.

Email: susildev2004@gmail.com 
controlled and directed (Wikipedia, 2014). Corporate governance refers to a set of rules and incentives by which the management of a company is directed and controlled (Velnampy, 2013). Corporate governance is the system by which business corporations are directed and controlled by distributing the rights and responsibilities among different participants, such as the board, managers, shareholders, and other stakeholders, and spells out the rules and procedures for decision on corporate affairs (Pradhan \& Adhikari, 2009). Corporate governance denotes the processes and structure that are responsible for the decision which have a very long team influence on the composition of management team, on capital structure, and on taking of important risks for the owners of the company (Awan \& Khan, 2012). Ruin (2001) stated that the corporate governance as a group of people getting together as one united body with task and responsibility to direct control and rule with authority. The concept of corporate governance is popular with the emergence of agency problem when the ownership of companies is separated from the control thereof.

Corporate governance leads to a lot of benefits to different levels of management and helps the organization to reduce the corruption in management level, which helps to enhance the value of the shareholders. Blair (1995) said that corporate governance implicates the whole set of legal, cultural, and institutional arrangements that determine what publicly traded corporations can do, who controls them, how that control is exercised, and how the risk and the return from the activities they undertake are allocated. Corporate governance issues arise in an organization whenever two conditions are present. First, there is an agency problem and second, transaction costs are such that the agency problem cannot be dealt with through a contract (Hart, 1995). The source of agency problem dates back to decade ago. In $18^{\text {th }}$ century, Adam Smith argued that "The directors of such joint stock companies, however, being the manager rather of other people's money than their own, it cannot well be expected, that they should watch over it with the same anxious vigilance with which the partners in a private company frequently watch over their own (Jensen \& Meckling, 1976). The objective of a corporation's shareholders is a return on their investment, managers are likely to have other goals, such as the power and prestige of running a large and powerful organization, or entertainment and other perquisites of their position. In this situation, managers' superior access to inside information and the relatively powerless position of the numerous and dispersed shareholders, mean that managers are likely to have the upper hand (Fama \& Jensen, 1983).

Maharjan (2017) studied the effect of corporate governance practice on financial performance of insurance companies in Nepal. The study employed descriptive cum analytical research design. Board size, number of board meetings, CEO 
duality, Audit committee are the explanatory variables for corporate governance. Firm size and age of the firms are also included as control variables to see the effect on the financial performance of Nepalese insurance Company. The performance of firms was measured using Return on Assets (ROA) and return on equity ROE. The study concluded that there exists relationship between the corporate governance practices and firms' financial performance. The board meeting and audit committee were found to positively affect the financial performance of insurance companies. Board size is found to be negative but not significant. The study also concludes CEO duality has the negative impact on the performance of the insurance company. Firm with large in size with high board meeting tend to perform well. Age of the company also positively influenced on the financial performance of insurance companies in Nepal.The main purpose of this study is to examine the relationship between corporate governance and the performance of the insurance companies in Nepal. The other specific objectives are to explore the relationship between corporate governance variable with firm performance as measured by ROA and ROE.

The first section of the study deals with the introduction, problem, scope and objective of the study. The second chapter will discuss about the research methodology. Section three is about the empirical results and the final section draws the conclusion. Discussion of the implication of the study as well is made on the last section.

\section{The Methodology}

The research is descriptive cum analytical research design. The population for the study includes all the 40 insurance companies in Nepal. Seven out of 18 life insurance companies and eight out of 20 nonlife insurance companies are selected as sample using convenient sampling technique. The study is about the Role of corporate governance on the performance of insurance companies of Nepal. The study examines the effects of independent variables on the performance of insurance companies of Nepal. The selected companies for the study purpose are presented in the annex 1 . The study use five year data from 2011/12 to 2015/16 with 100 firm year observations. Data were collected from mail survey and published data from respective insurance company and Beema Samiti. Data were analyzed using correlational analysis and multiple linear regression models.

\section{The Model}

The model assumes that the performance of the insurance companies depends on the several variables of corporate governance. The corporate governance variables are size of the board, audit committee, firm size, board independence and compliance. The model takes the following form: 
Firm performance $=\mathrm{fCG}$ variables $\}$

This means,

Performance of the insurance company $(\mathrm{y})=$

$\beta_{0}+\beta_{1} * \mathrm{FO}+\beta_{2} * \mathrm{DE}+\beta_{3} * \mathrm{BS}+\beta_{4} * \mathrm{FS}+\beta_{5} \mathrm{FA}+\beta_{6} * \mathrm{FG}+\mathrm{e}_{\mathrm{i}}$

The independent variables consist of corporate governance variables and control variable as under $\mathrm{Y}=\mathrm{ROA}$ and $\mathrm{ROE}, \mathrm{FO}=$ Firm ownership, $\mathrm{DE}=$ Debt to equity ratio, $\mathrm{BS}=$ Board size, $\mathrm{FS}=$ Firm size, $\mathrm{FA}=$ Firm age, $\mathrm{FG}=$ Firm growth, e=error term

Where, the performance is used as a dependent variable and is measured in terms of ROA $=$ Return on Assets and ROE $=$ Return on Equity

\section{Firm Ownership}

There are numbers of researches into the relationship between ownership and the profitability of insurance company.

Various empirical studies show the relationship between ownership type and firm performance. Foreign ownership plays crucial role in a firm's performance, particularly in developing and transitional economies (Grog and Greenway, 2004). Most of these studies carried out in industrial and developing countries and they have argued that foreign banks are more profitable than domestic one in developing countries and less profitable in industrial countries (Chaanti, 1985).

$H_{1}$ : Foreign ownership is positively related to the performance of insurance company.

\section{Debt to Equity Ratio}

The Debt/Equity (D/E) Ratio is calculated by dividing a company's total liabilities by its shareholder equity. These numbers are available on the balance sheet of a company's financial statements. The ratio is used to evaluate a company's financial leverage (Investopedia, 2018).

The debt-to-equity ratio $(\mathrm{D} / \mathrm{E})$ is a financial ratio indicating the relative proportion of shareholders' equity and debt used to finance a company's assets. Closely related to leveraging, the ratio is also known as risk, gearing or leverage. The two components are often taken from the firm's balance sheet or statement of financial position (so-called book value), but the ratio may also be calculated using market values for both, if the company's debt and equity are publicly traded, or using a combination of book value for debt and market value for equity financially.

$H_{2}$ : Debt to equity is negatively related to the performance of insurance company. 


\section{Board Size}

Board size is a members of board committee or board director. There may be communication problem and complication if the board size is larger. The board size is the number of board members of the insurance companies. This study will examine the effect of the size of the board in the performance of the insurance company. According to Syriopoulos \& Tsatsaronis (2011) the board size has a negative impact on the firm's performance. The board of directors can be described in terms of size, structure, tenure and voting mechanisms. We intuitively understand that the size of group matters for decision making. However, our institution on this issue is saddled with ambiguities. On the one hand people are hardwired for the horse trading; hence it is easier to reach a common ground when fewer people are involved in decision making (Silva, 1993).

$H_{3}$ : The size of board is negatively related to the performance of the insurance company.

\section{Firm Size}

The firm size is a natural logarithm of total assets of the insurance company. According to Mehran (1995) the size of company is considered in this study as control variables to have a relationship with other factors. Optimum firm size is dependent on a variety of internal and external factors. Growing a company is like blowing up a balloon. Your first view breaths, though difficult, produce immediate results. Subsequent breaths expand the balloon proportionally until it nears capacity. On average, larger companies have better performance as they are able to diversify their risk (Ghosh, 1998). Furthermore, larger company has larger market share and market power in respect of customers and investment volume.

$\mathrm{H}_{4}$ : Size of firm is positively related to the performance of insurance company.

\section{Firm Age}

As the firm grows older, their performance and their brand become stronger. Consumer loyalty and the increased network help the firm to make better performance. The age has been determined by investigating of year of establishment. A newly established firm has less resources and faces even more difficulties up to reaching break-even point. Older company can occupy the larger portion of market whereas it becomes difficult for new one.

H5: Firm age is positively related to the performance of insurance company.

\section{Firm Growth}

The growth of the firm is the increment rate of the value of assets and liability of the firm. As the firm grows larger, the performance of the firm increases because 
growth of the firm helps to increase the strength and competency of firm. So, firm makes strategy to increase the growth rate at the expected level.

H6: Firm age is positively related to the performance of insurance company.

\section{Return on Assets}

The amount of net income returned as a percentage of shareholder's equity. Return on equity measures a corporation's profitability by revealing how much profit a company generates with the money shareholders have invested. Return on assets is not useful for comparisons between industries because of factors of scale and peculiar capital requirements such as reserve requirements in the insurance and banking.

\section{Return on Equity}

The amount of net income returned as percentage of shareholders' equity Return on equity measures a corporation's profitability by revealing how much profit a company generates with the money shareholders have invested (Investopedia, 2018). It is often said to be the ultimate ratio or the 'mother of all ratios' that can be obtained from a company's financial statement. It measures how profitable a company is for the owner of the investment, and how profitably a company employs its equity (Ratios, 2013). The above discussion can be summarized in theoretical framework in Figure 2.1

\section{Conceptual Framework}

\begin{tabular}{|l|l|}
\hline Governance variables & Firm Performance \\
\hline Board size & ROA \\
firm growth & \\
Debt to equity & \\
Firm size & \\
Age & \\
\hline
\end{tabular}

Independent variables

Dependent variables

Figureshowstheconceptualframeworkwherecorporategovernanceissuesare measured by boardsize, ownership type, firm growth, debt to equity, firm size and age. Return on assets, return on equity are the dependent variables of firms' performance. 


\begin{tabular}{|l|l|}
\hline Firm Performance (Dependent Variables) & Description \\
\hline ROA=Return on Assets & Net income/Total Assets \\
\hline ROE=Return on Equity & Net income/Total Equity \\
\hline
\end{tabular}

Independent and control variables

\begin{tabular}{|l|l|}
\hline $\begin{array}{l}\text { Corporate Governance (Independent } \\
\text { variables) }\end{array}$ & Description and Measurement \\
\hline $\mathrm{BS}=$ Board Size & No. ofmembers in a board. \\
\hline $\mathrm{FO}=$ Foreign ownership & Foreign $=1$, otherwise $=0$ \\
\hline
\end{tabular}

\section{Control Variables}

\begin{tabular}{|l|l|}
\hline Independent Variables & Description \\
\hline FS = Firm Size & $\begin{array}{l}\text { Value of the firm (total Assets) } \\
\text { Log of total assets }\end{array}$ \\
\hline Age & No of years the firm has been established \\
\hline Debt to Equity & Total debt /Total equity \\
\hline Firm Growth & Growth in net assets \\
\hline
\end{tabular}

\section{Result and Discussion}

Descriptive statistics shows the mean, standard deviation, minimum and maximum return on assets ranges from negative -0.5 to 19.03 percent, leading to the average return on assets of 1.78 percent. Return on equity ranges from negative 52.71 percent to 193.02 percent, leading the average return on equity to 15.01 percent. Standard deviation on ROA is 1.825 percent. This signifies that there is a little variation in the mean value of ROA in Nepalese insurance companies.

The mean value of return on equity is 15.01 percent. Debt to equity ranges from negative 106.2 to 142.74 percent, firm growth ranges from negative 93.01 percent to 317.29 percent, firm size ranges from 1491.81 to 1929.63 percent, firm age ranges from 8 to 69 years, board size ranges from 5 directors to 9 directors and foreign ownership ranges from 10 percent to 100 percent in Nepalese insurance companies. The average firm growth has been observed to 27.54 percent while average firm size is 168.28 percent. The average firm age and board size are observed to be 16.48 years and 7 directors respectively while average foreign ownership is 18.69 percent in Nepalese insurance companies. 
Table 2: Descriptive Statistics

\begin{tabular}{llllll}
\hline & $\mathrm{N}$ & Minimum & Maximum & Mean & St. Deviation \\
\hline Return on Assets & 134 & -0.0050 & 0.1903 & 0.01780 & 0.01825 \\
Return on Equity & 138 & -0.5271 & 1.9302 & 0.1501 & 0.2297 \\
Debt to Equity & 114 & -1.0621 & 1.4274 & 0.2202 & 0.3343 \\
Firm Growth & 107 & -0.9301 & 3.1729 & 0.2754 & 0.4648 \\
Firm Size & 138 & -14.9181 & 19.291 & 1.6828 & 0.7574 \\
Firm Age & 139 & 8 & 6.9 & 16.48 & 16.324 \\
Board Size & 137 & 5 & 9 & 7.09 & 1.325 \\
Foreign Ownership & 30 & 0.10 & 1.00 & 0.1869 & 0.2059 \\
Valid N (list wise) & 30 & & & & \\
\hline
\end{tabular}

\section{Correlation Analysis}

Correlation analysis is performed in order to obtain an understanding the relationship among all the variables. Return on asset is positively correlated debt to equity ratio, firm size, and age of the firm. However, ROA has a negative relation with firm growth, board size and foreign ownership. Firm growth, board size and foreign ownership have very less impact on insurance company's ROA. ROE has overall negative relationship exist with firm growth, firm size, firm age, board size and foreign ownership. On the other hand, there is a positive relationship between ROE and debt to equity ratio. Debt to equity has a negative relationship with firm growth, firm size and firm age.

Board size of foreign ownership has a positive relationship with debt to equity ratio. Increase in the number of board of directors and foreign ownership increases the debt to equity ratio. Similarly, firm growth has a positive relationship with firm age, board size and foreign ownership, whereas firm size has negative impact on firm growth. Firm size has negative relationship with board size and foreign ownership. Firm size has positive relationship with firm age. Firm with longer period of establishment has a bigger firm size. The firm age has negative relationship with board size and foreign ownership. Board size has positive impact on foreign ownership. Firms having foreign ownership have more number of board members and vice versa. 
Table 3: Correlation Matrix for the Dependent and Independent Variables

\begin{tabular}{|c|c|c|c|c|c|c|c|c|}
\hline & $\begin{array}{l}\text { Return } \\
\text { on } \\
\text { Assets }\end{array}$ & $\begin{array}{l}\text { Return } \\
\text { on } \\
\text { Equity }\end{array}$ & $\begin{array}{l}\text { Debt to } \\
\text { Equity }\end{array}$ & $\begin{array}{l}\text { Firm } \\
\text { Growth }\end{array}$ & $\begin{array}{l}\text { Firm } \\
\text { Size }\end{array}$ & $\begin{array}{l}\text { Firm } \\
\text { Age }\end{array}$ & $\begin{array}{l}\text { Board } \\
\text { Size }\end{array}$ & $\begin{array}{l}\text { Foreign } \\
\text { Ownership }\end{array}$ \\
\hline $\begin{array}{l}\text { Return on } \\
\text { Assets }\end{array}$ & 1 & & & & & & & \\
\hline $\begin{array}{l}\text { Return on } \\
\text { Equity }\end{array}$ & 0.02 & 1 & & & & & & \\
\hline $\begin{array}{l}\text { Debt to } \\
\text { Equity }\end{array}$ & 0.104 & 0.479 & 1 & & & & & \\
\hline $\begin{array}{l}\text { Firm } \\
\text { Growth }\end{array}$ & -0.007 & -0.108 & -0.111 & 1 & & & & \\
\hline Firm Size & 0.122 & -0.048 & $-0.403 * *$ & -0.056 & 1 & & & \\
\hline Firm Age & 0.44 & -0.164 & $-0.618 * *$ & 0.028 & $0.622 * *$ & 1 & & \\
\hline Board Size & -0.063 & -0.091 & 0.049 & 0.068 & $-0.224 *$ & $-0.89 * *$ & 1 & \\
\hline Foreign & - & $-0.789 * *$ & -0.111 & 0.121 & $-0.483 * *$ & - & 0.040 & 1 \\
\hline Ownership & $0.741 * *$ & & & & & $0.702 * *$ & & \\
\hline
\end{tabular}

1. ${ }^{*}$ Correlation is significant at the 0.01 level (2-tailed)

2. * Correlation is significant at the 0.05 level (2-tailed)

\section{Regression Analysis}

The regression of corporate governance and control variables on the performance of insurance companies has been analyzed by defining the performance of insurance companies in terms of return on equity, return on assets.

\section{Estimated Relationships between Return on Assets and Firm Specific Variables}

Table 4 reflects the regression analysis of the effect of corporate variables on the firm performance as measured by ROA. For this purpose univitiate and multi vitiate regression model have been employed. Model 1 to 6 are univitiate as each corporate governance variable is regress on the ROA. Model 7, 8 and 9 are multivariate regression model used to see the effect of the control variable along with considered variable to the dependent variable ROA.

Board size, Debt to equity and firm growth are negatively related with return on assets. The beta coefficient of board size is negative at 1 percent level of significant indicate that the result is as per the prior hypothesis. This result reveals that higher the board size lower will be the profitability of the firm and vice versa. The negative impact of debt to equity with ROA is as per the prior hypothesis but it is not significant. The negative causal relationship of firm growth is contradictory as per prior hypothesis but it is not significant. The other variable like debt to equity has a negative impact on ROA; however, the beta coefficients are not significant at 5 percent level of significance. The beta coefficient of firm ownership is found to be positive in both univitiate and multivariate regression model which is as per the 
prior hypothesis indicates that foreign ownership has positive impact on ROA. Firm size is found to be positively related with ROA however it is found to be negatively related in multivariate regression model significant at 1 percent level of significant. This indicates that larger the firm growth, lower would be the return on assets. However, the beta coefficient is not significant at 5 percent level of significance. The result also indicates that larger the portion of foreign ownership, lower would be the return on assets and beta coefficient is also significant. The multivariate regression result shows that firm size, ownership type and board size variables are found to be significant. The result is presented in the table below.

Table 4: Estimated Relationships between Return on Assets and Firm Specific Variables

\begin{tabular}{|c|c|c|c|c|c|c|c|c|c|c|}
\hline & & Regress & ion Coef & ficient of & & & & & & \\
\hline Models & Intercept & $\mathrm{DE}$ & $\mathrm{FG}$ & FS & FA & FO & BS & $\mathrm{R}^{2}$ & SEE & $\mathrm{F}$ \\
\hline 1 & $\begin{array}{l}0.016 \\
(6.991)^{*}\end{array}$ & $\begin{array}{l}-0.006 \\
(1.033)\end{array}$ & & & & & & 0.01 & 0.0212 & 1.068 \\
\hline 2 & $\begin{array}{l}0.012 \\
(14.401)\end{array}$ & & $\begin{array}{l}-9.081 \\
-0.058)\end{array}$ & & & & & 0 & 0.0081 & 0.002 \\
\hline 3 & $\begin{array}{l}-0.039 \\
(-0.951)\end{array}$ & & & $\begin{array}{l}0.004 \\
(1.401)\end{array}$ & & & & 0.015 & 0.0201 & 1.941 \\
\hline 4 & $\begin{array}{l}0.019 \\
(7.357)^{*}\end{array}$ & & & & $\begin{array}{r}6.310 \\
0.551)\end{array}$ & & & 0.001 & 0.0202 & 0.300 \\
\hline 5 & $\begin{array}{c}0.028 \\
(19.659) *\end{array}$ & & & & & $\begin{array}{l}. .017 \\
-5.868)^{*}\end{array}$ & & 0.549 & 0.0029 & 34.62 \\
\hline 6 & $\begin{array}{l}(18.26)^{*} \\
0.001\end{array}$ & & & & & & $\begin{array}{l}0.056 \\
3.45)^{*}\end{array}$ & 0.69 & 0.004 & 34.43 \\
\hline 7 & $\begin{array}{l}-0.090 \\
(-1.51)\end{array}$ & $\begin{array}{l}0.012 \\
(1.741)\end{array}$ & & $\begin{array}{l}0.007 \\
(1.803)\end{array}$ & & & & 0.039 & 0.0212 & 2.149 \\
\hline 8 & $\begin{array}{l}0.074 \\
(-1.030)\end{array}$ & $\begin{array}{l}0.013 \\
(1.602)\end{array}$ & & $\begin{array}{l}0.004 \\
(1.19)\end{array}$ & $\begin{array}{l}4.901 \\
(0.254)\end{array}$ & & & 0.042 & 0.0211 & 1.277 \\
\hline 9 & $\begin{array}{l}-0.029 \\
(-1.3)\end{array}$ & & & $\begin{array}{c}0.004 \\
(2.223)^{*}\end{array}$ & & $\begin{array}{l}(0.012) \\
(- \\
5.012)^{*}\end{array}$ & $\begin{array}{l}-0.04 \\
3.88^{*}\end{array}$ & 0.631 & 0.0031 & 22.631 \\
\hline
\end{tabular}

\section{Figures in parentheses are t-values}

2. The signs * and ** denote that the results are significant at 1 percent and 5 percent level of significance respectively.

\section{Estimated Relationships between Return on Equity and Firm Specific Variables}

The relation of firm specific variables on ROE show that Board size, firm age, and are negatively related with return on equity but found not significant. The beta coefficient of board size and found to be negative which is as per prior hypothesis but not significant. The other variable like, age, ownership, is negatively related to the return on equity which is a contradictory result. However, these variables are found to be not significant at all. The beta coefficient of firm size and growth is 
positively related with ROE which is as per the prior hypothesis but not found to be significant at 1 percent level.

The beta coefficient of debt to equity and firm ownership is found to be negatively related with return on equity at 1 percent level of significant. This result is as per the prior hypothesis. The negative relation indicates that higher the debt to equity lower will be the return on equity and vice versa. The beta coefficient of foreign ownership variable is also found to be positively related with ROE indicating foreign owner companies have the positive impact on ROE

Table 5: Estimated Relationships between Return on Equity and Firm Specific Variables

\begin{tabular}{|c|c|c|c|c|c|c|c|c|c|c|}
\hline \multicolumn{11}{|c|}{ Regression Coefficient of } \\
\hline Models & Intercept & $\mathrm{DE}$ & FG & FS & BS & FA & FO & $\mathrm{R}^{2}$ & SEE & $\mathrm{F}$ \\
\hline 1 & $\begin{array}{l}0.0745 \\
(5.406)^{*}\end{array}$ & $\begin{array}{l}-0.210 \\
(6.06)^{*}\end{array}$ & & & & & & 0.229 & 0.1196 & 35.012 \\
\hline 2 & $\begin{array}{l}0.1119 \\
(6.340)^{*}\end{array}$ & & $\begin{array}{l}0.038 \\
(- \\
1.101)\end{array}$ & & & & & 0.014 & 0.1411 & 1.202 \\
\hline 3 & $\begin{array}{l}0.406 \\
(0.891)\end{array}$ & & & $\begin{array}{c}0.019 \\
-0.612)\end{array}$ & & & & .003 & 0.2300 & 0.351 \\
\hline 4 & $\begin{array}{l}0.239 \\
(2.299)^{*}\end{array}$ & & & & $\begin{array}{l}-0.017 \\
(- \\
0.989)\end{array}$ & & & 0.008 & 0.2299 & 0.101 \\
\hline 5 & $\begin{array}{l}0.201 \\
(6.798)^{*}\end{array}$ & & & & & $\begin{array}{l}-0.002 \\
(-1.198\end{array}$ & & 0.029 & 0.2301 & 3.671 \\
\hline 6 & $\begin{array}{l}0.324 \\
(18.91)\end{array}$ & & & & & & $\begin{array}{l}0.271 \\
(- \\
6.94) *\end{array}$ & 0.634 & 0.0042 & 48.251 \\
\hline 7 & $\begin{array}{l}0.069 \\
(3.800)^{*}\end{array}$ & $\begin{array}{l}-0.223 \\
(5.804)^{*}\end{array}$ & $\begin{array}{l}0.031 \\
(- \\
0.809)\end{array}$ & & & & & 0.305 & 0.1198 & 17.669 \\
\hline 8 & $\begin{array}{l}0.156 \\
(1.968)\end{array}$ & & $\begin{array}{l}0.038 \\
(- \\
1.069)\end{array}$ & & $\begin{array}{l}-0.005 \\
(-0.46)\end{array}$ & & & 0.017 & 0.1453 & 0.692 \\
\hline 9 & $\begin{array}{l}0.329 \\
(17.471)\end{array}$ & & $\begin{array}{l}0.007 \\
(- \\
0.189)\end{array}$ & & & & $\begin{array}{l}0.27 \\
(- \\
6.71)^{*}\end{array}$ & 0.635 & 0.0449 & 23.295 \\
\hline 10 & $\begin{array}{l}0.129 \\
(1.658)\end{array}$ & $\begin{array}{l}-0.29 \\
(5.821)^{*}\end{array}$ & $\begin{array}{l}0.031 \\
(-0.9)\end{array}$ & & & & & 0.308 & 0.11198 & 12.016 \\
\hline 11 & $\begin{array}{l}0.179 \\
(1.781)\end{array}$ & $\begin{array}{l}-0.192 \\
(3.610)^{*}\end{array}$ & $\begin{array}{l}0.039 \\
(- \\
0.951)\end{array}$ & & & $\begin{array}{l}-0.001 \\
(-0.951)\end{array}$ & & 0.318 & 0.1221 & 9.031 \\
\hline
\end{tabular}

1. Figures in parentheses are t-values

2. The signs * and ** denote that the results are significant at 1 percent and 5 percent level of significance respectively. 


\section{Concluding Remarks}

This paper aimed at role of corporate governance on the financial performance of Nepalese insurance sector. The study used secondary data from 2009/10 to 2016/17 comprising of 7 insurance company that include 8 non-life leading to 15 sample companies with 135 firm year observation using convenient sampling technique. The study used descriptive cum analytical research design with regression analysis to see the causal relationship among the variables. The study concludes that corporate governance affects the firm performance in Nepalese insurance sector. Board size has a negative impact on ROA while firm size and firm ownership have a positive impact on ROA and ROE. The variable debt to equity has the negative and significant impact on ROE respectively. The finding of the study is useful at policy level for further improvement of insurance industry in practicing good governance. The result finds that increased in the frequency of board meeting help to resolve the timely settlement of the problem and increased the efficiency of the Nepalese insurance industry. Efficient and effective system helps to maintain the proper. The study can be further carried out with inclusion of the other corporate governance variables like independent director, board composition, number of audit meeting, leverage, and ownership structure. Further board and CEO qualification, experience, frequency of audit meetings were not considered in the study. Comparative corporate governance can also be carried out between life and non- life insurance company.

\section{References}

Awan, S.H., \& Khan, A. (2012). Effect of board composition on firm performance: A case of Pakistani listed company. Interdisciplinary Journal of Contemporary Research in Business, 853-866.

B. K. A., Mahato, A., Thapa, S., Rai, A., \& Devkota, N. (2019). Achieving Nepal's sustainable development goals (SDGs) by effective compliance of corporate governance. Quest Journal of Management and Social Sciences, 1(1), 50-72.

Blair, M. (1995). Ownership and control: Rethinking corporate governance for the twenty first century. Washington: Brooking Institution.

Chaanti, R. (1985). Corporate board size composition and corporate and corporate failure in the Retailing industry. Journal of Management Studies, 22, 400-416.

Fama, E. F., \& Jensen, M. C. (1983). Agency problems and residual claims. The journal of law and Economics, 26(2), 327-349. 
Ghosh, A. (1998). Does accounting base performance really improve following corporate acquisions? New York, USA: ZIckling School of Business, Baruch College (CUNY).

Görg, H., \& Greenaway, D. (2004). Much ado about nothing? Do domestic firms really benefit from foreign direct investment?. The World Bank Research Observer, 19(2), 171-197.

Hart, O. (1995). Corporate governance: some theory and implications. The economic journal, 105(430), 678-689.

Investopedia, L. L. C. (2018). Jnvestopedia. Retrieved from https.

Jensen, M. C., \& Meckling W. H. (1976). Theory of firms, managerial behaviors, agency costs and ownership structure. Journal of Financial Economics, 305306.

Maharjan, R. (2017). The effect of corporate governance on financial performance of insurance companies in Nepal. Presented in international Conference on Business, Society and Governance, Emerging Management Paradigm, Feb, 2628.

Mehran, H. (1995). Executive compensation structure, ownership, and firm performance. Journal of financial economics, 38(2), 163-184.

Pradhan, R.S., \& Adhikari, S.N. (2009). Corporate governance and firm performance. Management Review.

Ratios, R. (2013). Return On Equity (ROE). Retrieved, 8(8), 2013.

Ruin, J. E. (2001). Essentials of corporate management. Kuala Lumpur: Malaysian Institute of Corporate governance (MICG).

Shah, S.Z., Butt, S.A., \& Saeed, M. M. (2011). Ownership structure and performance of firms: Empirical evidence from an emerging market. Financial Journal of Business Management, 5(2), 515-523.

Silva, J. L. (1993). Effects of pressure on large multimeric proteins and viruses. In High Pressure Chemistry, Biochemistry and Materials Science (pp. 561578). Springer, Dordrecht.

Syriopoulos, T., \& Tsatsaronis, M. (2011). The corporate governance model of the shipping firms: financial performance implications. Maritime Policy \& Management, 38(6), 585-604. 
Velnampy, T. (2013). Corporate governances and firm performance: A study of Sri Lankan manufacturing companies. Journal of Economics and Sustainable Development. 